\title{
Kadar Total Suspended Solid pada Air Sungai Nguneng Sebelum dan Sesudah Tercemar Limbah Cair Tahu
}

\section{Total Suspended Solid Content in Nguneng River Water Before and After Tainted with Liquid Tofu Waste}

\section{DEWI ARUM YULIANTI}

\author{
Jurusan Analis Kesehatan Poltekkes Kemenkes Semarang \\ Jl. Wolter Monginsidi Pedurungan Tengah Semarang \\ E-mail:dewiarumyulianti@gmail.com
}

\begin{abstract}
Abstrak
Industri tahu dalam proses produksinya menghasilkan limbah cair yang menimbulkan masalah pencemaran, sehingga merusak lingkungan. Limbah cair tahu mengandung senyawa-senyawa organik sehingga menyebabkan kadar Total Suspended Solid (TSS) yang tinggi. Total Suspended Solid (TSS) yang mengendap di dasar sungai, akan membentuk lumpur yang dapat mengganggu aliran air sungai serta menyebabkan pendangkalan sungai. Mengetahui perbedaan kadar TSS pada air Sungai Nguneng sebelum dan sesudah tercemar limbah cair tahu. Penelitian observasional analitik dengan pendekatan cross sectional. Sampel yang digunakan yaitu air Sungai Nguneng sebelum dan sesudah tercemar limbah cair tahu, kemudian dilakukan pemeriksaan kadar TSS secara duplo dengan lima kali pengulangan berdasarkan hari yang berbeda. Analisa data menggunakan uji Paired Sample $T$-Test dengan derajat kepercayaan 95\%. Rata-rata kadar TSS yang diperoleh pada air Sungai Nguneng sebelum tercemar limbah cair tahu adalah $220,4 \mathrm{mg} / \mathrm{l}$. Rata-rata kadar TSS yang diperoleh pada air Sungai Nguneng sesudah tercemar limbah cair tahu adalah 558,4 mg/l. Uji Peired Samples T-Test dengan tingkat kesalahan 5\% dan signifikasi .000 $(p<0,05)$. Terdapat perbedaan kadar TSS pada air Sungai Nguneng sebelum dan sesudah tercemar limbah cair tahu.
\end{abstract}

Kata Kunci: Total Suspended Solid (TSS) ; Limbah Cair Tahu ; Air Sungai

\begin{abstract}
The tofu industry in production process produces liquid waste causing pollution problems, so damaging the environment. Liquid waste tofu contains organic compounds causing high levels of Total Suspended Solid (TSS). Total Suspended Solid (TSS) that settles at the bottom of the river, will form a mud that can disrupt the flow of river water and cause siltation of the river causing siltation of the river. To know the difference of TSS content in Nguneng River water before and after contaminated with tofu waste. Analytical observational research with cross sectional approach. The samples used were Nguneng River water before and after contaminated with tofu waste, then examined TSS levels in duplo with five repetitions based on different days. Data analysis using Paired Sample T-Test with 95\% confidence degree. The average TSS levels obtained in Nguneng River water before polluted tofu waste was $220.4 \mathrm{mg} / \mathrm{l}$. The average TSS levels obtained in Nguneng River water after contaminated tofu liquid waste were $558.4 \mathrm{mg} / \mathrm{l}$. Peired Samples T-Test test with $5 \%$ error rate and significance of $0(p<0.05)$. There is a difference of TSS content in Nguneng River water before and after contaminated with tofu liquid waste.
\end{abstract}

Keyword: Total Suspended Solid (TSS) ; Tofu Liquid Waste ; River Water 


\section{Pendahuluan}

Penyakit Industri tahu merupakan usaha yang didirikan dalam rangka pengembangan kegiatan dibidang pangan yang mempunyai dampak positif dan negatif bagi lingkungan. Dampak positif berupa pemenuhan kebutuhan masyarakat akan sumber pangan, sedangkan dampak negatif dari adanya industri tahu berupa limbah cair yang menimbulkan masalah pencemaran, sehingga merusak lingkungan (Fachrurozi, dkk, 2010).

Berdasarkan hasil survei yang telah dilakukan oleh peneliti pada tanggal 1 November 2017 terdapat 9 industri tahu yang membuang limbah cair tahu ke Sungai Nguneng. Sungai Nguneng terletak di Desa Prambatan Lor, Kecamatan Kaliwungu, Kabupaten Kudus. Sungai Nguneng di bagian hulu memiliki debit sebesar $0,365 \mathrm{~m}^{3} /$ detik dan bagian hilir memiliki debit sebesar $0,373 \mathrm{~m}^{3} /$ detik.

Menurut Peraturan Daerah Jawa Tengah Nomor 5 Tahun 2012, limbah cair tahu memiliki karakteristik yang terdiri dari : Total Suspended Solid (TSS), Temperatur, pH, Chemical Oxygen Demand (COD) dan Biological Oxygen Demand (BOD).

Limbah cair tahu dihasilkan dari proses pencucian, perebusan, pengepresan dan pencetakan tahu, sehingga kuantitas limbah cair yang dihasilkan sangat tinggi. Limbah cair tahu mengandung senyawa-senyawa organik sehingga menyebabkan limbah cair tahu mengandung Total Suspended Solid (TSS) yang tinggi (Alaerts \& Sumestri, 2004).

Total Suspended Solid (TSS) adalah residu dari padatan total yang tertahan oleh kertas saring dengan ukuran partikel maksimal $2 \mu \mathrm{m}$ (SNI 06-6989.3-2004). Total Suspended Solid (TSS) merupakan parameter fisika dari pemeriksaan kualitas air. Pemeriksaan Total Suspended Solid (TSS) pada penelitian ini menggunakan metode gravimetri sesuai dengan SNI 06-6989.3 Tahun 2004.

Berdasarkan Peraturan Daerah Jawa Tengah Nomor 5 Tahun 2012 kadar maksimum Total Suspended Solid (TSS) pada limbah cair industri tahu sebesar $100 \mathrm{mg} / \mathrm{L}$.

Kadar Total Suspended Solid (TSS) yang tinggi pada air sungai akan menyebabkan air sungai tersebut menjadi keruh. Kekeruhan akan menghalangi masuknya sinar matahari ke dasar sungai. Terhalangnya sinar matahari untuk masuk ke dasar sungai menyebabkan proses fotosintesis terganggu. Proses fotosintesis yang terganggu mengakibatkan turunnya kadar oksigen terlarut yang dilepas ke dalam air sungai oleh tanaman. Turunnya kadar oksigen terlarut dalam air sungai akan mengganggu ekosistem sungai tersebut. Kadar oksigen terlarut di dalam air sungai yang menurun secara terus menerus akan mengakibatkan tanaman serta organisme yang berada di sungai tersebut lama-lama akan mengalami kematian (Alaerts \& Sumestri, 2004).

Total Suspended Solid (TSS) yang mengendap di dasar sungai , maka akan membentuk lumpur yang dapat mengganggu aliran air sungai serta menyebabkan pendangkalan sungai (Soemirat, 2004).

\section{Metode}

Jenis Penelitian yang digunakan adalah penelitian observasional analitik dengan pendekatan Cross-sectional.

Pengujian kadar Total Suspended Solid menggunakan metode gravimetri. Sampel yang digunakan pada penelitian ini adalah air Sungai Nguneng sebelum dan sesudah tercemar limbah cair tahu dengan Rancangan Acak Lengkap (RAL).

Penelitian ini dilakukan dengan 5 kali pengulangan berdasarkan hari yang berbeda, menggunakan rumus Gomez and gomez (Hanafiah, 1995) dan pemeriksaan dilakukan secara duplo, sehingga didapatkan unit penelitian sebanyak 20 sampel.

Data diuji menggunakan program komputer SPSS 16.0 for Windows (Spread sheet for statistic). Data yang dikumpulkan diuji dengan uji kenormalan menggunakan Uji Saphiro-Wilk karena jumlah sampel $<50$ dengan derajat kepercayaan 95\% $(\alpha=0,05)$, kemudian dilakukan uji Paired Sample T-Test karena kedua sampel tersebut saling berhubungan. 


\section{Hasil dan Pembahasan}

Berdasarkan Pengambilan sampel dilakukan pada tanggal 1 - 5 April 2018, pengambilan sampel dilakukan pada pukul 14.00 WIB. Berdasarkan hasil pengukuran debit yang dilakukan oleh peneliti untuk menentukan titik pengambilan sampel. Debit yang diperoleh sebesar $<5 \mathrm{~m}^{3} /$ detik pada air Sungai Nguneng sebelum dan sesudah tercemar limbah cair tahu, maka pengambilan sampel dilakukan di tengah sungai dengan kedalaman $0,5 \mathrm{~m}$ dari permukaan air sungai. Sampel dimasukkan ke dalam jerigen plastik dengan volume $1000 \mathrm{ml}$, kemudian dimasukkan ke dalam cool box dan segera dibawa ke laboratorium untuk dilakukan pemeriksaan.

Berdasarkan penelitian yang telah dilakukan diperoleh data sebagai berikut:

Tabel.1 Hasil Pemeriksaan Kadar Total Suspended Solid (TSS)

\begin{tabular}{ccc}
\hline $\begin{array}{c}\text { Hari } \\
\text { Ke- }\end{array}$ & Sampel & $\begin{array}{c}\text { Rerata Kadar } \\
\text { TSS (mg/l) }\end{array}$ \\
\hline 1 & SB & 205 \\
1 & SS & 525 \\
2 & SB & 220 \\
2 & SS & 540 \\
3 & SB & 235 \\
3 & SS & 555 \\
4 & SB & 211 \\
4 & SS & 580 \\
5 & SB & 231 \\
5 & SS & 592 \\
\hline
\end{tabular}

Keterangan :

SB : Sampel Sebelum Tercemar Limbah Cair Tahu

SS : Sampel Sesudah Tercemar Limbah Cair Tahu

Tabel.1 menunjukkan hasil rata-rata kadar Total Suspended Solid (TSS) pada sampel air Sungai Nguneng sebelum dan sesudah tercemar limbah cair tahu selama 5 (lima) hari. Berdasarkan penelitian yang telah dilakukan pada sampel air Sungai Nguneng sebelum tercemar limbah cair tahu pada hari ke - 1 didapatkan rerata kadar Total Suspended Solid (TSS) sebesar $205 \mathrm{mg} / \mathrm{l}$, hari ke - $2220 \mathrm{mg} / \mathrm{l}$, hari ke - $3235 \mathrm{mg} / \mathrm{l}$, hari ke - $4211 \mathrm{mg} / \mathrm{l}$, dan hari ke - $5231 \mathrm{mg} / \mathrm{l}$.

Sampel air Sungai Nguneng sesudah tercemar limbah cair tahu pada hari ke - 1 didapatkan rerata kadar Total Suspended Solid (TSS) sebesar $525 \mathrm{mg} / 1$, hari ke - $2540 \mathrm{mg} / \mathrm{l}$, hari ke - $3555 \mathrm{mg} / \mathrm{l}$, hari ke - 4 580, hari ke - $5592 \mathrm{mg} / \mathrm{l}$.

Rerata kadar Total Suspended Solid (TSS) pada air Sungai Nguneng sebelum dan sesudah tercemar limbah cair tahu selama 5 (lima) hari dapat dilihat pada gambar.1 berikut:

Gambar 1. Diagram Hasil Pemeriksaan Kadar Total Suspended Solid (TSS)

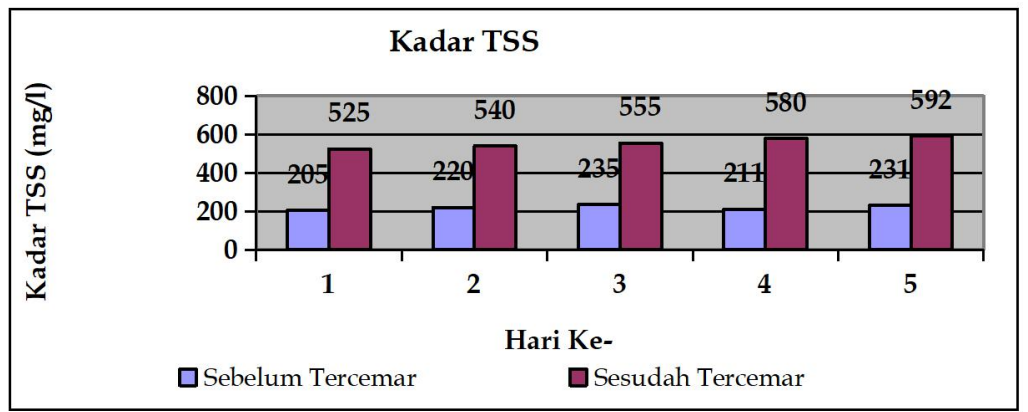


Berdasarkan gambar.1 dapat dilihat bahwa kadar Total Suspended Solid (TSS) pada air Sungai Nguneng sebelum tercemar limbah cair tahu secara keseluruhan lebih rendah dibandingkan dengan kadar Total Suspended Solid (TSS) pada air Sungai Nguneng sesudah tercemar limbah cair tahu. Kadar Total Suspended Solid (TSS) pada air Sungai Nguneng sebelum tercemar limbah cair tahu cenderung mengalami peningkatan, namun pada hari ke-4 mengalami penurunan, pada air Sungai Nguneng sesudah tercemar limbah cair tahu secara keseluruhan mengalami peningkatan.

Secara keseluruhan rata - rata kadar Total Suspended Solid (TSS) pada air Sungai Nguneng sebelum tercemar limbah cair tahu yaitu sebesar 220,4 mg/1 dan sesudah tercemar limbah cair tahu yaitu sebesar 558,4 mg/l.

Rerata kadar Total Suspended Solid (TSS) pada air Sungai Nguneng sebelum dan sesudah tercemar limbah cair tahu secara keseluruhan dapat dilihat pada gambar.2 berikut:

Gambar 2. Diagram Rerata Kadar Total Suspended Solid (TSS)

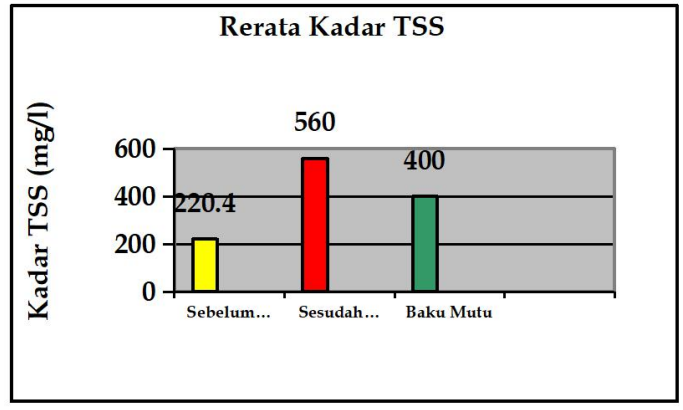

Hasil pengamatan menunjukkan pencemaran limbah cair tahu mempengaruhi besarnya kadar TSS pada sampel sesudah tercemar (Gambar 4.3). Apabila dibandingkan dengan baku mutu maka sampel sebelum tercemar tidak melebihi ambang batas yang ditentukan, namun pada sampel sesudah tercemar melebihi ambang batas yang ditentukan.

Menurut Peraturan Daerah Jawa Tengah Nomor 5 Tahun 2012, limbah cair tahu memiliki karakteristik yang terdiri dari : Total Suspended Solid (TSS), Temperatur, $\mathrm{Ph}$, Chemical Oxygen Demand (COD), dan Biological Oxygen Demand (BOD 5 ).

Berdasarkan hasil pemeriksaan kadar Total Suspended Solid (TSS) pada air Sungai Nguneng sebelum tercemar limbah cair tahu cenderung mengalami peningkatan, namun pada hari ke-4 mengalami penurunan yang disebabkan karena berkurangnya kecepatan aliran air sehingga sebagian Total Suspended Solid (TSS) terendapkan dan debit aliran air berkurang. Berkurangnya kecepatan aliran air maka menyebabkan debit air semakin kecil, debit air akan mempengaruhi kadar Total Suspended Solid (TSS) (Dewa, et al, 2016).

Berdasarkan klasifikasi mutu air yang telah ditetapkan dalam Peraturan Pemerintah Republik Indonesia Nomor 82 Tahun 2001 Tentang Pengelolaan Kualitas Air dan Pengendalian Pencemaran Air, Sungai Nguneng masuk dalam kelas IV (empat) karena air Sungai Nguneng digunakan untuk mengairi pertanaman dan kadar maksimum kandungan Total Suspended Solid (TSS) yang diperbolehkan pada air sungai kelas IV (empat) adalah sebesar $400 \mathrm{mg} / \mathrm{l}$.

Kadar Total Suspended Solid (TSS) pada air Sungai Nguneng sebelum tercemar limbah cair tahu secara keseluruhan dibawah baku mutu yang telah ditetapkan dalam Peraturan Pemerintah Republik Indonesia Nomor 82 Tahun 2001. Kadar Total Suspended Solid (TSS) di bawah baku mutu yang telah ditetapkan karena pada bagian hulu belum tercemar oleh limbah cair tahu, hanya tercemar oleh limbah cair rumah tangga. Limbah cair rumah tangga merupakan limbah cair yang berasal dari kegiatan rumah tangga. Komposisi limbah cair rumah tangga rata-rata mengandung bahan organik, anorganik dan senyawa mineralyang berasal dari sisa makanan, urin, serta sabun (Puji,2009).

Berdasarkan penelitian yang dilakukan oleh Alfrida E. Suoth dan Ernawita Nazir (2016) Limbah cair rumah tangga dinilai sebagai air limbah yang kadar pencemarnya ringan 
dibandingkan dengan air limbah yang berasal dari kegiatan industri. Komposisi pada limbah cair rumah tangga tidak berpotensi tinggi terhadap kadar Total Suspended Solid (TSS).

Kadar Total Suspended Solid (TSS) pada air Sungai Nguneng sebelum tercemar limbah cair tahu tertinggi terjadi pada hari ke-3. Hal ini dikarenakan debit air mengalami peningkatan yang cukup tinggi sehingga sedimen dasar perairan teraduk, sedimen yang teraduk mengakibatkan tingkat Total Suspended Solid (TSS) di badan air semakin tinggi (Andara, 2014). Kadar terendah terjadi pada hari ke-1 yang disebabkan karena rendahnya kecepatan aliran air sehingga sebagian Total Suspended Solid (TSS) terendapkan dan debit aliran air berkurang (rendah) (Dewa, et al, 2016).

Kandungan Total Suspended Solid (TSS) memiliki hubungan yang erat dengan kejernihan perairan. Semakin rendah kadar Total Suspended Solid (TSS), maka akan semakin tinggi nilai oksigen terlarut dan kejernihan (Dewa, et al, 2016).

Kadar Total Suspended Solid (TSS) pada air sungai sesudah tercemar limbah cair tahu secara keseluruhan di atas baku mutu yang telah ditetapkan yang disebabkan adanya limbah cair tahu yang dihasilkan oleh 9 (sembilan) industri dan juga limbah cair rumah tangga, hal ini mengindikasikan limbah cair tahu mengandung Total Suspended Solid (TSS) yang tinggi.

Kadar tertinggi terjadi pada hari ke - 5 dikarenakan tingginya kecepatan aliran air sehingga sedimen di dasar perairan tercampur dan menimbulkan tingginya kadar Total SuspendedSolid (TSS) dan terendah terjadi pada hari ke - 1. Keberadaan Total SuspendedSolid (TSS) tersebut akan menghalangi penetrasi cahaya yang masuk ke dalam perairan sehingga hubungan antara Total Suspended Solid (TSS) dan kejernihan akanmenunjukkan hubungan yang berbanding terbalik (Andara, 2014).

Berdasarkan hasil pengujian statistik menggunakan program SPSS 16.0 for Windows (Spread Sheet for Statistic), pada uji normalitas data menggunakan uji Saphiro-Wilk karena jumlah sampel kurang dari 50 didapatkan nilai sig .679 pada sampel sebelum tercemar limbah cair tahu dan .802 pada sampel sesudah tercemar limbah cair tahu yang menunjukkan data tersebut tersebar atau terdistribusi normal karena nilai sig. (signifikansi/nilai probabilitasnya) $>0,05$ (Aritonang,2005). Persebaran data yang normal, maka dapat dilanjutkan dengan uji Paired Sample T - Test dengan derajat kepercayaan 95\% $(\alpha=0,05)$ didapatkan nilai sig .000. Berdasarkan nilai sig. yang didapatkan, nilai tersebut $<0,05$ yang menunjukkan $\mathrm{Ho}_{\mathrm{o}}$ ditolak, dan $\mathrm{H}_{\mathrm{a}}$ diterima, yang menunjukkan bahwa ada perbedaan kadar Total Suspended Solid pada air Sungai Nguneng sebelum dan sesudah tercemar limbah cair tahu.

\section{Simpulan dan Saran}

\section{Simpulan}

Siswa Kadar Total Suspended Solid (TSS) pada air Sungai Nguneng sebelum tercemar limbah cair tahu rata - rata secara keseluruhan sebesar 220,4 mg/1.

Kadar Total Suspended Solid(TSS) pada air Sungai Nguneng sesudah tercemar limbah cair tahu rata - rata secara keseluruhan sebesar 558,4 mg/l.

Kadar Total Suspended Solid (TSS) pada air Sungai Nguneng sebelum tercemar limbah cair tahu secara keseluruhan di bawah baku mutu yang telah ditetapkan, tetapi kadar Total Suspended Solid (TSS) pada air Sungai Nguneng sesudah tercemar limbah cair tahu melebihi baku mutu yang telah ditetapkan.

Ada perbedaan kadar Total Suspended Solid (TSS) pada air Sungai Nguneng sebelum dan sesudah tercemar limbah cair tahu.

\section{Saran}

Siswa Bagi pengelola industri tahu seharusnya sebelum melakukan pembuangan limbah cair tahu ke badan perairan, terlebih dahulu dilakukan pengolahan agar dapat mengurangi kadar cemaran, terutama untuk parameter Total Suspended Solid dan lebih aman terhadap lingkungan. 
Bagi pengelola industri tahu dapat memanfaatkan limbah cair tahu, misalnya sebagai pupuk cair dan biogas.

Bagi pengelola industri tahu dapat melakukan pembuatan IPAL untuk pengolahan limbah cair tahu sebaiknya dilakukan bersama-sama dengan sembilan industri tahu yang berada di Desa Prambatan Lor sehingga biaya yang dikeluarkan setiap industri tidak banyak.

Bagi peneliti selanjutnya sebaiknya melakukan penelitian pada saat tidak musim hujan sehingga kondisi lingkungan stabil, maka dengan kondisi lingkungan yang stabil dapat menunjukkan bahwa kadar Total Suspended Solid (TSS) yang di hitung menunjukkan kadar yang sebenarnya.

\section{Daftar Pustaka}

Alaerts dan Sumestri, S.S. 2004.Metode Penelitian Air.Surabaya:Usaha Nasional.

Andara, Diani Riezki., Haeruddin., Agung Suryanto. 2014. Kandungan Total Sunpended Solid, Biochemical Oxigen Demand, dan Chemical Oxigen Demand serta Indeks Pencemaran Sungai Klampisan di Kawasan Industri Candi Semarang. 3(3). from http://ejournal-S1.undip.ac.id.

Aritonang R., Lerbin, R. 2005. Kepuasan Pelanggan, Pengukuran dan Penganalisaan dengan SPSS. Gramedia Pustaka Utama: Jakarta.

Dewa, Charista., Liliya Dewi Susanawati., Bambang Rahadi Widiatmono. 2015. Daya Tampung Sungai Gede Akibat Pencemaran Limbah Cair Industri Tepung Singkong di Kecamatan Ngadiluwih Kabupaten Kediri. from http://jsal.ub.ac.id.

Fachrurozi, M., Utami Liestiatie Budi., Suryani, Dyah. 2010. Pengaruh Variasi Biomassa pistia stratiotes L Terhadap Penurunan Kadar BOD, COD dan TSS Limbah Cair Tahu di Dusun Klero Sleman Yogyakarta. 4(1), 1-75, from https://media.neliti.com.

Hanafiah, Kemas Ali. 1995. Rancangan Percobaan (Teori \& Aplikasi). Jakarta: PT Raja Grafindo Persada.

Peraturan Pemerintah. 2001. Peraturan Pemerintah Republik Indonesia Nomor 82 Tahun 2001 Tentang Pengelolaan Kualitas Air dan Pengendalian Pencemaran Air. Retrieved November 5, 2017, from https://jdih.menlh.go.id.

Peraturan Daerah. Peraturan Daerah Jawa Tengah Nomor 5 Tahun 2012 Tentang Baku Mutu Air Limbah. Retrieved November 20, 2017, from https://www.jdihukum.jatengprov.go.id.

Puji., Nur Rahmi. 2009.Pengolahan Limbah Cair Domestik Menggunakan Lumpur Aktif Proses Anaerob. Universitasa Diponegoro. Fakultas Teknik Semarang. Soemirat. 2004.Kesehatan Lingkungan.Yogyakarta:Gadjah Mada University.

Standar Nasional Indonesia. SNI 06-6989.3-2004. Tentang Air dan air limbah-Bagian 3: Cara Uji Padatan Tersuspensi Total (Total Suspended Solid,TSS) secara gravimetri. Retrieved November 3, 2017, from https://www.sni.bsn.go.id.

Suoth, Alfrida E., Ernawita Nazir. 2016. Karakteristik Air Limbah Rumah Tangga pada Salah Satu Perumahan Menengah Ke atas yang Berada di Tangerang Selatan. 10(2). from: http://ejournal.farda.mof,org. 